\title{
Capabilities of Traffic Enforcers in Implementing Traffic Rules and Regulations in Nueva Ecija
}

\author{
Clara J. Carpio \\ Nueva Ecija University of Science and Technology Philippines \\ *Corresponding author: Clara J. Carpio: clarajcarpio@yahoo.com
}

Received 21 January 2020; $\quad$ Accepted 28 January 2020;

Published 31 January 2020

\begin{abstract}
It is generally accepted that it is not possible to completely prevent vehicle crashes, but that some of the injuries and severity can be prevented or minimized by skilled traffic enforcer. The study used descriptive method as it describes the present condition. A total of 205 respondents composing of 155 commuters and 50 traffic enforcers were surveyed. Based on the findings of the study, the commuters perceived traffic enforcers to be knowledgeable, skilled and displaying good attitude in implementing traffic rules. Thus, it is recommended that the commuters also should educate themselves in traffic rules and regulations. The traffic enforcers perceived themselves to be knowledgeable, skilled and displaying good attitude in implementing traffic rules. Thus, it is recommended that the traffic enforcers should update their knowledge, skills, and attitude through seminars and trainings for them to improve continuously.
\end{abstract}

Keywords: Traffic, Traffic Enforcer, Traffic Police, Traffic Officer, Traffic Rules and Regulations

\section{INTRODUCTION}

It is generally accepted that it is not possible to completely prevent vehicle crashes, but that some of the injuries and severity can be prevented or minimized by skilled traffic enforcer. Redhwan and Karim (2010) stated that most cause of road traffic collisions is drivers ' lack of awareness about traffic regulations and laws, and drivers ' failure to comply with traffic rules and regulations. Thus, Borlongan (2007) emphasized that traffic laws should be strictly enforced in the highly urbanized Philippine cities; hence, traffic enforcers.

According to Al Mazruii (2015), Traffic enforcing goals are unclear to officers in current traffic policing strategies and practices, and this appeared to have a negative impact on road safety achievement.

Al Khaldi (2006) concluded that negative attitudes and practice of a driver can only be addressed by the traffic enforcer with aggressive enforcement of the regulation. Mohlala (2017) further concluded that traffic enforcers' presence must have high visibility, as defined, to deal with the lawlessness of the breach on all serious offences.

In light of the insights, the researcher would like to assess the capabilities of traffic enforcer/police/officers in Nueva Ecija in the implementation of Traffic Rules and Regulations.

\section{CONCEPTUAL FRAMEWORK}

According to Pienaar (2007), the traffic officer during an investigation into an accident should not only have sound knowledge of the road and the environment but also the effect of factors on the road and the environment that must be brought into contention.

Espada et al. (2008) stated that the assessment of the technical know-how of the road staff responsible for transport planning and traffic management is crucial.

Ramavhunga (2018) to address the challenges were; training to improve traffic officers ' abilities; continuous training to improve efficiency; increased involvement by the state to increase efficiency and diversify training to make it effective.

\section{OBJECTIVE OF THE STUDY}

This paper described the perception of commuters on the capabilities of traffic enforcers in implementing rules and regulations be described in terms of knowledge, skills, and attitude. Likewise, the traffic enforcer's self-assessment in implementing rules and regulations be described in terms of knowledge, skills, and attitude.

\section{METHODOLOGY}

The study used descriptive method as it describes the present condition. Descriptive Method is designed for the researcher to gather information about presenting existing conditions and to describe the nature of the situation as it exists at the time of the study and to explore the causes of particular phenomena (Camic et al., 2003). A total of 205 respondents composing of 155 commuters and 50 traffic enforcers were surveyed. The researcher used Likert-scale type questionnaire (Vagias, 2006) and analyzed it through statistical data treatment such as mean and weighted mean. 


\section{RESULTS AND DISCUSSION}

Perception of Commuters on the Capabilities of Traffic Enforcers in Implementing Traffic Rules and Regulations in Nueva Ecija

Table 1 Knowledge of Traffic Enforcers

\begin{tabular}{|l|l|l|}
\hline $\begin{array}{l}\text { Traffic Enforcers have knowledge } \\
\text { in... }\end{array}$ & WM & VI \\
\hline 1. License familiarity. & 3.77 & Agree \\
\hline 2. $\quad$ Traffic signs. & 3.96 & Agree \\
\hline 3. $\quad$ Safety gears. & 3.88 & Agree \\
\hline 4. $\quad$ Coding scheme. & 3.72 & Agree \\
\hline 5. Whistle code. & 3.80 & Agree \\
\hline Average Weighted Mean & 3.74 & Agree \\
\hline
\end{tabular}

Table 1 presented the knowledge of traffic enforcers based on the perception of commuters. Statement 2 obtained the highest weighted mean of (3.96) with a verbal interpretation of "Agree" while statement 4 obtained the lowest weighted mean of (3.72) with a verbal interpretation of "Agree."

Table 2 Skills of Traffic Enforcers

\begin{tabular}{|ll|l|l|}
\hline \multicolumn{2}{|l|}{ Traffic Enforcers have skills in... } & WM & VI \\
\hline 1. & Hand signals. & 3.73 & Agree \\
\hline 2. & Whistle manipulation. & 3.78 & Agree \\
\hline 3. & Managing traffic. & 4.12 & Agree \\
\hline 4. & Resolving traffic jam. & 3.62 & Agree \\
\hline 5. & Assisting traffic accident. & 3.82 & Agree \\
\hline Average Weighted Mean & 3.81 & Agree \\
\hline
\end{tabular}

Table 2 presented the skills of traffic enforcers based on the perception of commuters. Statement 3 gained the highest weighted mean of (4.12) with a verbal interpretation of "Agree" while statement 4 gained the lowest weighted mean of (3.62) with a verbal interpretation of "Agree."

Table 3 Attitude of Traffic Enforcers

\begin{tabular}{|ll|l|l|}
\hline \multicolumn{2}{|l|}{ Traffic Enforcers know how to.... } & WM & VI \\
\hline $1 . \quad$ Approach violators in a proper way. & 3.54 & Agree \\
\hline 2. & Entertain queries about traffic directions. & 3.70 & Agree \\
\hline 3. & Assist pedestrians. & 3.41 & Agree \\
\hline $\begin{array}{l}\text { 4. } \\
\text { Apply maximum tolerance in managing } \\
\text { the traffic. }\end{array}$ & 3.30 & Agree \\
\hline $\begin{array}{l}\text { 5. } \\
\text { Maintain professionalism in conducting } \\
\text { traffic by being fair and just. }\end{array}$ & 3.49 & Agree \\
\hline Average Weighted Mean & 3.49 & Agree \\
\hline
\end{tabular}

Table 3 presented attitude of traffic enforcers based on the perception of commuters. Statement 2 got the highest weighted mean of (3.70) with a verbal interpretation of "Agree" while statement 4 got the lowest weighted mean of "Agree".

Self-assessment of Traffic Enforcers on Their Capabilities of Implementing Traffic Rules and Regulations

Table 4 Knowledge of Traffic Enforcer

\begin{tabular}{|l|l|l|}
\hline $\begin{array}{l}\text { As a traffic enforcer, I have } \\
\text { knowledge in... }\end{array}$ & WM & VI \\
\hline 1. License familiarity. & 4.61 & Strongly Agree \\
\hline 2. Traffic signs. & 4.44 & Strongly Agree \\
\hline 3. Safety gears. & 4.44 & Strongly Agree \\
\hline 4. Coding scheme. & 4.00 & Strongly Agree \\
\hline 5. Whistle code. & 4.23 & Strongly Agree \\
\hline Average Weighted Mean & 4.34 & Strongly Agree \\
\hline
\end{tabular}

Table 4 presented the knowledge of traffic enforcers based on selfassessment. Statement 1 obtained the highest weighted mean of (4.61) with a verbal interpretation of "Strongly Agree" while statement 5 obtained the lowest weighted mean of (4.23) with a verbal interpretation of "Strongly Agree".

Table 5 Skills of Traffic Enforcer

\begin{tabular}{|l|l|l|}
\hline $\begin{array}{l}\text { As a traffic enforcer, I have skills } \\
\text { in... }\end{array}$ & WM & VI \\
\hline 1. hand signals. & 4.61 & Strongly Agree \\
\hline 2. whistle manipulation. & 4.02 & Agree \\
\hline 3. managing traffic. & 4.32 & Strongly Agree \\
\hline 4. resolving traffic jam. & 4.32 & Strongly Agree \\
\hline 5. assisting traffic accident. & 4.41 & Strongly Agree \\
\hline Average Weighted Mean & 4.34 & Strongly Agree \\
\hline
\end{tabular}

Table 5 presented the skills of traffic enforcers based on selfassessment. Statement 1 got the highest weighted mean of (4.61) with a verbal interpretation of "Strongly Agree" while statement 2 got the lowest weighted mean of (4.02) with a verbal interpretation of "Strongly Agree".

Table 6 Attitude of Traffic Enforcer

\begin{tabular}{|l|l|l|}
\hline $\begin{array}{l}\text { As a traffic enforcer, I know } \\
\text { how to... }\end{array}$ & WM & VI \\
\hline $\begin{array}{l}\text { 1. Approach violators in a proper } \\
\text { way. }\end{array}$ & 4.70 & Strongly Agree \\
\hline $\begin{array}{l}\text { 2. Entertain queries about traffic } \\
\text { directions. }\end{array}$ & 4.52 & Strongly Agree \\
\hline 3. Assist pedestrians. & 4.32 & Strongly Agree \\
\hline $\begin{array}{l}\text { 4. Apply maximum tolerance in } \\
\text { managing the traffic. }\end{array}$ & 4.32 & Strongly Agree \\
\hline $\begin{array}{l}\text { 5. Maintain professionalism in } \\
\text { conducting traffic by being fair } \\
\text { and just. }\end{array}$ & 4.38 & Strongly Agree \\
\hline Average Weighted Mean & 4.45 & Strongly Agree \\
\hline
\end{tabular}

Table 6 presented the attitude of traffic enforcers based on selfassessment. Statement 1 gained the highest weighted mean of (4.70) with a verbal interpretation of "Strongly Agree" while statements 3 and 4 gained the lowest weighted mean of (4.32) with a verbal interpretation of "Strongly Agree".

\section{CONCLUSION}

Based on the findings of the study, the commuters perceived traffic enforcers to be knowledgeable, skilled and displaying good attitude in implementing traffic rules. Thus, it is recommended that the commuters also should educate themselves in traffic rules and regulations. The traffic enforcers perceived themselves to be knowledgeable, skilled and displaying good attitude in implementing traffic rules. Thus, it is recommended that the traffic enforcers should update their knowledge, skills, and attitude through seminars and trainings for them to improve continuously.

\section{Data Availability}

All relevant data are within the paper and its supporting information files.

\section{Conflicts of Interest}

The author declared that there is no conflict of interest regarding the publication of this paper. 


\section{Funding Statement}

The author didn't receive any specific funding for this work.

\section{REFERENCES}

[1] Al Mazruii, M., Edwards, J., Armstrong, K., \& Davey, J. (2015). Policing of road safety in Oman: Perceptions and beliefs of traffic police officers.

[2] Al-Khaldi, Y. M. (2006). Attitude and practice towards road traffic regulations among students of health sciences college in Aseer region. Journal of family \& community medicine, 13(3), 109.

[3] Borlongan, A. M. (2007). Innovations in Standard Philippine English. Current research on English and applied linguistics: A De La Salle University special issue, 1-36.

[4] Camic, P. M., Rhodes, J. E., \& Yardley, L. E. (2003). Qualitative research in psychology: Expanding perspectives in methodology and design. American Psychological Association.

[5] Espada, I. C., Lidasan, H., De Leon, M., \& Planner, A. T. (2008). Enhancement of Capacity Building on Transport
Planning and Traffic Management in the Context of Philippine Local Cities: A Needs Assessment Approach. In 16th Annual Conference of the TSSP.

[6] Mohlala, S. (2017). The development of an implementation and management plan for the traffic management system in advancing the decade of action for road safety in South Africa, 2030 versus 2020. Southern African Transport Conference.

[7] Pienaar, J. F. (2007). Analysis of the training needs of traffic officers in the Potchefstroom district (Doctoral dissertation, North-West University).

[8] Ramavhunga, M. H. (2018). The challenges facing traffic officers in the management of traffic law in Limpopo Province with specific reference to Vhembe District (Doctoral dissertation).

[9] Redhwan, A. A., \& Karim, A. J. (2010). Knowledge, attitude and practice towards road traffic regulations among university students, Malaysia. Int Med J Malaysia, 9(2), 29-34.

[10] Vagias, W. M. (2006). Likert-type scale response anchors. clemson international institute for tourism. \& Research Development, Department of Parks, Recreation and Tourism Management, Clemson University. 